\section{"Distinctions of race, nationality, colour, and creed are unknown within the portals of the temple of Asculapius"}

This remark by William Osler (1849-1919), delivered in an address to the British Medical Association in Montréal on Sept. 1, $1897,{ }^{1}$ is relevantly lacking in a recent CMAJ article by Persaud and colleagues attributing racist sentiments to Osler. ${ }^{2}$

The subject of racism in medicine has come increasingly under the spotlight over the past few years, although the broader issue of inequality in health care has been studied for much longer. It is understandable, even desirable, that physicians from minority communities should be engaged in resolving such injustices, but a responsible rather than resentful approach is required. The insinuation that William Osler - modern medicine's most beloved professional icon ${ }^{3}$ - was racist is remarkable, and a considered study of his life and writings will make this abundantly clear. Osler's bibliography is brimming with both explicit and implicit remarks decrying divisiveness in all its forms and encouraging social harmony. His above-quoted remark is just one of many unambiguous statements encouraging professional tolerance and cohesion.

Persaud and colleagues ${ }^{2}$ seem to believe that Osler did not live up to his own stated ideals. "Not by the lips, but by the life," they might well say with Osler, "are men influenced in their beliefs." ${ }^{4}$ However, throughout his life, William Osler was a warm and approachable supporter of minority physicians, whenever he had contact with them. Walter Sydney Atkinson (1881-1978), ${ }^{5}$ Wu Lien-teh (1879-1960) ${ }^{6}$ and John Andrew Kenney Sr. (1874-1950) ${ }^{7}$ are good examples of racialized physicians who spoke highly of Osler's influence and character. Additionally, Osler was particularly indiscriminate in praising good medical work, and referenced contributions from diverse backgrounds in his lectures on The Evolution of Modern Medicine (April 1913). ${ }^{8}$ In July 1913 , he specifically sought out the Kurdish physician Dr. Sa'eed Khan, with views to personally restoring the Hamadan tomb of the Persian polymath Avicenna (circa 980-1037) - "one of the greatest names in the history of medicine," - a clear instance of Osler's respect for medicine's international heritage. ${ }^{9}$ Finally, Osler was strikingly liberal in his personal dealings with foreigners. Consider his observations regarding "the Musselman at prayer" during his 1911 visit to Egypt: "it seemed the very apotheosis of worship so simple, so fitting in its attitude and with words so appropriate to human feelings."10

William Osler was not racist, and he cannot be held personally responsible, as Persaud and colleagues imply, for the normalization of racial inequalities in medicine. The historical record is unequivocally clear concerning Osler's most attractive quality - his unconditional love for others - and this is consistently brought out in the reminiscences of his former colleagues and by those wishing to revitalize his legacy in more recent times. Osler may indeed have made a few offhand comments that we would disagree with if repeated today, but these remarks did not define him as a person and should not be used to denigrate his character 100 years after his death. Rather, he should be upheld as a powerful advocate for a profession free from racism.

\section{Nadeem Toodayan MBBS}

Medical registrar, The Wollongong Hospital, Wollongong, NSW, Australia
Cite as: CMAJ 2021 February 1;193:E173. doi: $10.1503 / \mathrm{cmaj} .77388$

\section{References}

1. Osler W. British medicine in Greater Britain. Boston Med Surg J 1897;137:221-7.

2. Persaud N, Butts H, Berger P. William Osler: saint in a "White man's dominion". CMAJ 2020;192:E1414-6.

3. Bliss M. William Osler: a life in medicine. New York: Oxford University Press; 1999.

4. Osler W. Science and immortality. Boston: Houghton Mifflin; 1904:37.

5. Atkinson WS. An Osler memorandum. JAMA 1970;211:2018.

6. Lien-teh W. Reminiscences of Sir William Osler in England. In: Maude Abbott, editor. Bulletin No. IX of the International Association of Museums, and Journal of Technical Methods. Sir William Osler Memorial Number. Toronto: Murray Printing Co.; 1926:388-391.

7. Kenney JA. The debt of modern medicine to Sir William Osler, Bart. J Natl Med Assoc 1946;38:81-5.

8. Osler W. The evolution of modern medicine: a series of lectures delivered at Yale University on the Silliman Foundation in April, 1913. New Haven (CT): Yale University Press; 1921:98.

9. Cushing H. The life of Sir William Osler, Vol. 2. Oxford (UK): The Clarendon Press; 1925:368-77.

10. Osler W. Letter from Egypt to Mrs. Mabel Brewster, dated 1911 Feb. 18. Sir William Osler Collection (CA OSLER P100) in the Osler Library of the History of Medicine, McGill University [letter].

Competing interests: The author is a foundation member of The William Osler Society of Australia and New Zealand (www.wosanz.org), and is an elected member of both The American Osler Society and Osler Club of London.

Content licence: This is an Open Access article distributed in accordance with the terms of the Creative Commons Attribution (CC BY-NC-ND 4.0) licence, which permits use, distribution and reproduction in any medium, provided that the original publication is properly cited, the use is noncommercial (i.e., research or educational use), and no modifications or adaptations are made. See: https://creativecommons.org/ licenses/by-nc-nd/4.0/

Acknowledgement: The author is indebted to Lily Szczygiel (documentation technician at the Osler Library) for providing a copy of Osler's original Egypt letter at short notice. 